\title{
Retraction Note to: Potential of soft computing approach for evaluating the factors affecting the capacity of steel-concrete composite beam
}

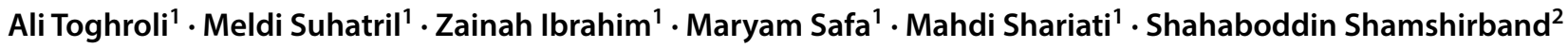

Published online: 14 January 2020

(c) Springer Science+Business Media, LLC, part of Springer Nature 2020

\section{Retraction To: \\ J Intell Manuf (2018) 29:1793-1801 https://doi.org/10.1007/s10845-016-1217-y}

The Editor-in-Chief has retracted this article (Toghroli et al. 2018) because validity of the content of this article cannot be verified. This article showed evidence of substantial text overlap (most notably with the articles cited Cojbasic et al. 2016; Mazinani et al. 2016; Mohammadian et al. 2016; Mansourvar et al. 2015) and authorship manipulation. Meldi Suhatril, Zainah Ibrahim, Maryam Safa, Mahdi Shariati and Shahaboddin Shamshirband do not agree to this retraction. Ali Toghroli has not responded to any correspondence about this retraction.

\section{References}

Cojbasic, Z., et al. (2016). Surface roughness prediction by extreme learning machine constructed with abrasive water jet. Precision Engineering, 43, 86-92. https://doi.org/10.1016/j.precisione ng.2015.06.013.

Mansourvar, M., Shamshirband, S., Raj, R. G., Gunalan, R., \& Mazinani, I. (2015). An automated system for skeletal maturity assessment by extreme learning machines. PLoS ONE, 10(9), e0138493. https://doi.org/10.1371/journal.pone.0138493.

The original article can be found online at https://doi.org/10.1007/ s10845-016-1217-y.

\footnotetext{
Maryam Safa

maryamsafa1991@gmail.com

1 Department of Civil Engineering, University of Malaya, 50603 Kuala Lumpur, Malaysia

2 Department of Computer System and Technology, Faculty of Computer Science and Information Technology, University of Malaya, 50603 Kuala Lumpur, Malaysia
}

Mazinani, I., et al. (2016). Estimation of Tsunami bore forces on a coastal bridge using an extreme learning machine. Entropy, 18(5), 167. https://doi.org/10.3390/e18050167.

Mohammadian, E., Motamedi, S., Shamshirband, S., et al. (2016). Application of extreme learning machine for prediction of aqueous solubility of carbon dioxide. Environmental Earth Science, 75, 215. https://doi.org/10.1007/s12665-015-4798-4.

Toghroli, A., Suhatril, M., Ibrahim, Z., et al. (2018). Potential of soft computing approach for evaluating the factors affecting the capacity of steel-concrete composite beam. Journal of Intelligent Manufacturing, 29, 1793. https://doi.org/10.1007/s10845-016-1217-y.

Publisher's Note Springer Nature remains neutral with regard to jurisdictional claims in published maps and institutional affiliations. 